\title{
Level of Trust, Knowledge and Religiosity Against Muzakki's Interest in Issuing Zakat at BAZNAS Salatiga City
}

\author{
Heru Prastyo ${ }^{1^{\star}}$, Tri Yunianto², Rugaya Renwarin ${ }^{3}$ \\ 1,2,3/AIN Salatiga, Indonesia \\ Email: heruprastyo99@iainsalatiga.ac.id
}

\begin{abstract}
This research aim to to know: (1) Influence level trust to enthusiasm of Muzakki in releasing religious obligatory, (2) Knowledge to enthusiasm of Muzakki in releasing religious obligatory, (3) Religiusitas to enthusiasm of Muzakki in releasing religious obligatory, (4) Influence between level trust, and knowledge of religiusitas to enthusiasm of Muzakki in releasing religious obligatory in BAZNAS Town of Salatiga. Type Research which is used in this thesis is research of combination (methods mixed) between quantitative diskripsi and diskripsi qualitative. Determination of sampel use method of purposive sampling. Sampel obtained by counted 80 responder of muzakki which paying religious obligatory in BAZNAS Salatiga. Pursuant to result of research in Body of Amil Religious Obligatory National (BAZNAS) Town of Salatiga indicate that: Trust storey;level have an effect on positive and signifikan to enthusiasm of muzakki, Knowledge have an effect on positive and signifikan to enthusiasm of muzakki, Religiusitas have an effect on positive and signifikan to enthusiasm of muzakki, and Storey;Level trust, and knowledge of religiusitas by together influence by signifikan enthusiasm variable of muzakki in [Releasing] Religious obligatory in Body of Amil Religious Obligatory National (Baznas) Town of Salatiga.
\end{abstract}

Keywords: Level Trust, Knowledge, Religiusitas, Enthusiasm of Muzakki.

\section{A. INTRODUCTION}

In Islamic law, zakat demonstrates that Islam is very concerned about social issues, particularly the fate of the vulnerable, in order to foster closer loving ties between people and realize Islamic brotherhood. In essence, zakat is an order from Allah SWT that must be carried out, with the payment of zakat being viewed as having a similar urgency to the creation of prayer (Sudirman, 2007: 22).

The issue of zakat and welfare is inextricably linked to Islamic economics. Every citizen's dream is to live in a state of welfare. In reality, hardly everyone qualifies for government assistance (Siti Kalimah 2018). When a person reaches his nishab, he must pay zakat, which is one of Islam's third pillars, for the possessions he owns. In Q.S At-Taubah (9): 103, Allah's requirement to give zakat is reiterated as follows: Take zakat from some of their possessions, clean and purify them, and pray for them with that zakat. Your prayer, verily, (becomes) peace of mind for them. Allah, on the other hand, is All Hearing and All-Knowing (Surah At Taubah: 103).

The National Amil Zakat Agency (BAZNAS) was established in the national capital, BAZNAS Province, and Regency/City, as a result of efforts to achieve success in the management of zakat in line with the law of the Republic of Indonesia 
Number 23 of 2011. BAZNAS is a non-structural government agency that is selfgoverning and reports to the President via the Minister. BAZNAS is an institution with the authority to manage zakat on a nationwide level. (Peraturan BAZNAS, 2016). Because of the culture of the Indonesian people, who prefer to pay zakat personally rather than through zakat distribution institutions, especially BAZNAS, the acceptance of zakat in zakat institutions has not been perfect. This societal habit has been for a long time, and changing it will not be possible in a short period of time (Hikayah Azizi, 2008).

Salatiga City is one of the religiously diverse cities with good zakat potential, as evidenced by the Muslim community's revenue in four sub-districts: Argomulyo, Sidorejo, Sidomukti, and Tingkir. However, zakat collection is still not optimal, which could be due to a number of causes.

The level of trust influences Muzakki's willingness to issue zakat. Muzakki intends to rely on zakat institutions to distribute their zakat to zakat mustahiq since these institutions are professional, trustworthy, and transparent, according to Muzakki. The public will be more trusting as a result of this (Kanji Lusiana, 2017: 6).

The amount of education is another aspect that influences tithing interest. Knowledge refers to the importance of one's grasp of sharia norms, particularly those concerning zakat requirements, in influencing one's decision to provide zakat to mustahiq zakat. The greater one's understanding of an object, the more likely one is to act in ways that are consistent with the object. When a person has a thorough understanding of his responsibilities, such as issuing zakat, he will carry them out effectively and accurately.

In article 168 of the Law of the Republic of Indonesia Number 38 of 2009, it is stated that the proceeds of zakat collection are used for the benefit of mustahik in accordance with sharia provisions, and that the proceeds of zakat collection are used according to a priority scale of mustahik needs and can be used for productive businesses. (Peraturan Perundang-undangan Republik Indonesia Nomor 38 Tahun 2011).

This research focuses on the characteristics that determine muzakki's desire in issuing zakat in Baznas Salatiga City, such as their level of trust, knowledge, and religion. This city is home to individuals of various religions and beliefs, including Muslims, Christians, and Buddhists; nonetheless, in their daily lives, they live in harmony, work together, aid one another, and respect one another among religious people. These three factors are intertwined, with the internal interest factor being the most important and being driven by social factors such as social interaction and emotional encouragement. After social interaction, the person sees and believes, thinks, acts on comfort, and feels obligated, resulting in an interest in paying zakat.

Based on this explanation, researchers are encouraged to raise this issue in the form of a study entitled "The Effect of Trust, Knowledge and Religiosity Levels on Muzakki's Interest in Issuing Zakat at the National Amil Zakat Agency (Baznas) of Salatiga City." 
In accordance with the formulation of the problem, the objectives of this study are a) To determine the effect of the level of trust on Muzakki's interest in issuing zakat in Baznas Salatiga City; b) To determine the level of knowledge of Muzakki's interest in issuing zakat in the Salatiga City Baznas; c) To find out the effect of religiosity on Muzakki's interest in issuing zakat in Baznas Salatiga City; d) To determine the effect of the level of trust, knowledge, and religiosity on Muzakki's interest in issuing zakat in the Baznas of Salatiga City.

The research's theoretical benefits are expected to be employed in the development of scientific treasures, particularly in terms of zakat, as well as an academic reference and input for future research. In practice, this research is expected to provide a realistic image of the factors that influence muzakki's interest in providing zakat maal, particularly for the people of Salatiga City and the Islamic community in general. As an introduction to science relevant to the amil zakat institution for the general population. This is an initial discovery that researchers will use to perform more research on the amount of trust, knowledge, religion, and interest in tithing.

Study (Satrio and Siswantoro 2016), the findings of empirical research suggest that affluence, belief, and religiosity have a major impact on muzakki's desire to pay zakat through the Amil Zakat Institution. Research result (Setiawan 2018) according to the findings, religion, trust, and reputation all had a statistically significant impact on muzakki's interest in distributing professional zakat through the Amil Zakat Institution in Ponorogo.

Study (Pospos 2018), (1) In Baitul Maal, Langsa City, the enthusiasm of coffee shop proprietors in paying zakat is unaffected by their income. (2) Service has an impact on the interests of zakat-paying coffee shop owners in Baitul Maal Langsa City. (3) Trust has no bearing on the will of coffee shop owners to pay zakat. Zakat can be paid at Baitul Maal Langsa City.

Hasil penelitian (Nur and Zulfahmi 2018), The result shows that all independent variables which are identified as Knowledge (X1), income (X2), and trust (X3) simultaneously influence the dependent variable which is identified as muzakki's motivation in paying zakat at BaitulMal, Lhokseumawe (Y). The result suggests that knowledge (X1) and trust (X3) partially influence the muzakki's motivation in paying zakat, while income (X2) does not influence the motivation.

According to the findings of the study (Salmawati and Fitri 2018), 44.8 percent of the population lives in poverty. Four independent variables can be used to explain the dependent variable Intention to pay zakat. Income, religiosity, accountability, and quality service are all factors that influence muzakki inclination to pay zakat in Baitul Mal, Banda Aceh.

According to (Yunus 2016), trust and contribution factors have an influence on the process of determining interest by traders in issuing zakat in Baitul Mal Lhokseumawe, either partially or simultaneously testing, while the religiosity factor has a smaller influence on determining interest by traders in issuing zakat. 
According to this study, there is a research gap that stems from earlier research used as material in doing research connected to the author's study.

\section{B. LITERATURE REVIEW}

The following are the hypotheses in this study, which are based on the theoretical foundation and framework of thought mentioned above:

The influence of the level of trust on Muzakki's interest in issuing zakat in the Salatiga City Baznas. Our belief in a particular product or feature is referred to as trust. These ideas are based on how people learn and experience things (Muhammad Taufiq Amir, 2005: 8). If people trust in zakat organizations, they will be interested and prepared to pay tithes to them.

The most essential aspect in affecting people's willingness to pay zakat in amil zakat organizations is their level of confidence. A more professional handling of zakat money will make the amil zakat institution the community's preferred method of zakat payment and will encourage others to do so as well. According to Ferry Setiawan, the amount of trust is the most important factor in affecting muzakki's attention. This demonstrates that muzakki are interested in paying professional zakat through zakat organizations for a variety of reasons, one of which being the belief that zakat institutions are competent and trustworthy in terms of zakat management (Fery Setiawan, 2017: 11).

Based on the description above, the following hypothesis can be formulated: Hypothesis 1: The higher the level of trust, the higher Muzakki's interest in issuing zakat at the National Amil Zakat Agency (Baznas) Salatiga City.

The effect of knowledge on Muzakki's interest in issuing zakat in the Salatiga City Baznas. The benefit of one's comprehension of sharia norms is knowledge. Particularly in relation to the zakat responsibility, it has a significant impact on one's awareness of the need to issue zakat to mustahiq zakat, therefore it can be argued that the better one's knowledge of an object (the zakat obligation), the more likely one is to act in line with the object. (Kanji Lusiana, 2017: 6).

In Baitul Mal, Lhokseumawe City, Mukhlish Muhammad Nur and Zulfahmi stated that the level of knowledge had a partial and substantial effect on the interest of muzakki to pay zakat (Nur and Zulfahmi 2018). Based on the description above, the following hypothesis can be formulated: Hypothesis 2: The higher the level of knowledge, the higher Muzakki's interest in issuing zakat at the National Amil Zakat Agency (Baznas) of Salatiga City.

The influence of religiosity on Muzakki's interest in issuing zakat in the Salatiga City Baznas. According to sociology of religion, a high level of religiosity improves one's comprehension of sharia principles, particularly those linked to zakat responsibilities, which has a significant impact on one's awareness of mustahiq zakat. In Baitul Mal, Banda Aceh City, Salmawati and Meutia Fitri stated that religiosity has an impact on muzakki's desire to pay zakat. As a result, as the religiosity variable rises, muzakki's desire to pay zakat rises as well (Salmawati and Fitri 2018). 
According to Islam, religiosity encompasses all social, political, economic, and other activities undertaken in the context of surrendering to Allah. According to Islam, religiosity encompasses all social, political, economic, and other activities undertaken in the context of surrendering to Allah (Djamaludin Ancok dan Fuat Nashori Suroso, 2000: 2). Muzakki who have met the zakat-related markers of religiosity are always committed to distributing zakat in accordance with the laws. The following hypothesis can be made based on the previous description:

Hypothesis 3: The higher the religiosity, the higher Muzakki's interest in paying zakat at the National Amil Zakat Agency (Baznas) Salatiga City. The influence of the level of trust, knowledge, and religiosity on Muzakki's interest in issuing zakat in the Baznas of Salatiga City.

The lack of public interest in paying zakat at zakat institutions is influenced by characteristics like as trust, knowledge, and religiosity. A more professional handling of zakat money will make the amil zakat institution the community's preferred method of zakat payment and will encourage others to do so as well. At the Amil Zakat Institute, Eko Satrio and dodik highlighted that trust and religion have a big impact on people's willingness to pay zakat (Satrio and Siswantoro 2016). Knowledge, Income, and Trust, according to Mukhlish Muhammad Nur and Zulfahmi, all influence muzakki's desire to pay zakat (Nur and Zulfahmi 2018). The following hypothesis can be made based on the previous description:

Hypothesis 4: The higher the level of trust, knowledge and religiosity, the higher Muzakki's interest in issuing zakat at the National Amil Zakat Agency (Baznas) of Salatiga City.

\section{METHOD}

The method utilized is a mixed-methods approach that combines quantitative and qualitative descriptions. All factors in this study are based on primary and secondary data. Muzakki who pay zakat through BAZNAS Salatiga in 2019 are the unit of analysis (Consuelo G Sevilla, 2007: 182).

This study will take place in the city of Baznas Salatiga. Salatiga was chosen as the research location because it is a city full of diversity, with a Muslim population of 136,870 people, Protestant Christians 30,193 people, Catholics 9,035 people, Hindus 98 people, and Buddhists 882 people, indicating that Islam and the places where they live are embraced by the majority of the population. The religious services are near to each other, making it ideal for research. There were 412 muzakki in this survey, all of them had paid zakat through the National Amil Zakat Agency (BAZNAS) Salatiga. The number of research samples has been reduced to 80.

Three independent variables and one dependent variable were used to collect data. Level of Trust (X1), Knowledge (X2), Religiosity (X3), and Muzakki Interests (X3) were used as variables (Y). 


\section{RESULT AND DISCUSSION}

\section{Multiple Lineer Regression Test}

Multivariate data is analyzed using this regression. With more than one independent variable, this analysis is used to forecast the value of the dependent variable (at least two variables).

Table 1. Multiple Linear Regression Test Results

Coefficients ${ }^{\mathrm{a}}$

\begin{tabular}{|c|c|c|c|c|c|}
\hline \multirow[b]{2}{*}{ Model } & \multicolumn{2}{|c|}{$\begin{array}{c}\text { Unstandardized } \\
\text { Coefficients }\end{array}$} & \multirow{2}{*}{\begin{tabular}{|c|}
$\begin{array}{c}\text { Standardized } \\
\text { Coefficients }\end{array}$ \\
Beta \\
\end{tabular}} & \multirow[b]{2}{*}{$\mathrm{t}$} & \multirow[b]{2}{*}{ Sig. } \\
\hline & B & Std. Error & & & \\
\hline (Constant) & $-4,133$ & 2,400 & & $-1,722$ & 089 \\
\hline Tingkat Kepercayaan & ,422 & ,085 & ,372 & 4,969 &, 000 \\
\hline Pengetahuan & ,488 & ,099 & ,394| & $4,917 \mid$ & , 000 \\
\hline Religiusitas & 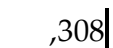 & ,090 & 261 & 3,423 & 001 \\
\hline
\end{tabular}

a. Dependent Variable: Minat Muzakki

Based on the data in table 1 . it can be made multiple linear regression equation models as follows: $Y=-4,133+0,422 X 1+0,488 X 2+0,308 X 3$

Where:

a. Constant (a)

This means that if all of the independent variables are zero (0), the dependent variable (beta) has a value of -4.133 .

b. Knowledge level (X1) of Muzakki's Interests (Y)

With the assumption that the other independent variables in the regression model are fixed, the knowledge level coefficient value of 0.422 suggests that for every one unit rise in knowledge level, the $\mathrm{Y}$ variable will increase by 0.422 .

c. Knowledge (X2) of Muzakki's Interests (Y)

With the assumption that the other independent variables in the regression model remain unchanged, the knowledge coefficient value of 0.488 suggests that for every one unit increase in knowledge, the $Y$ variable will increase by 0.488 .

d. Religiosity (X3) to Muzakki's Interests (Y)

With the assumption that the other independent variables in the regression model remain fixed, the knowledge coefficient value of 0.308 suggests that for every one unit rise in religiosity, the $\mathrm{Y}$ variable will increase by 0.488 .

\section{Coefficient of Determination Test $\left(\mathbf{R}^{2}\right)$}

The coefficient of determination $\left(\mathrm{R}^{2}\right)$ indicates the strength of the relationship between the dependent and independent variables, or the extent to which the independent variable's contribution influences the dependent variable (Anton Bawono, 2006: 92). The coefficient of determination $\left(R^{2}\right)$ is used to determine the magnitude of the independent variable's influence on the dependent variable in 
percentages $(\%)$. The coefficient of determination $\left(\mathrm{R}^{2}\right)$ of this study's results are as follows:

Table 2. Coefficient of Determination Test $\left(\mathbf{R}^{2}\right)$ Model Summary ${ }^{b}$

\begin{tabular}{|l|r|r|r|r|}
\hline Model & $\mathrm{R}$ & R Square & \multicolumn{1}{|c|}{$\begin{array}{c}\text { Adjusted R } \\
\text { Square }\end{array}$} & $\begin{array}{c}\text { Std. Error of the } \\
\text { Estimate }\end{array}$ \\
\hline 1 &, $826^{\mathrm{a}}$ &, 683 &, 670 & 1,47424 \\
\hline
\end{tabular}

a. Predictors: (Constant), Religiusitas, Tingkat Kepercayaan, Pengetahuan

b. Dependent Variable: Minat Muzakki

Table 2 shows that the correlation coefficient $(R)$ is 0.826 , indicating that the dependent variable (muzakki interest) and the independent variable (degree of belief, knowledge, and religion) have a strong association because it is close to 1 . The contribution of the independent variable impacts the dependent variable of 68.3 percent interest in muzakki may be explained by the contribution of the variables level of trust, knowledge, and religion, according to the coefficient of determination $\left(\mathrm{R}^{2}\right)$ of 0.683 . Other variables outside the research equation model influence the remainder $(100$ percent -68.3 percent $=31.7$ percent $)$.

\section{3. $t$ test (Individual Parameter Significance Test)}

The $t$ test is used to determine the level of significance of the independent variable's effect on the dependent variable on an individual or group basis. The following is the foundation for making decisions:

a. If the value of sig $<0.05$ or $t$ count $>t$ table then there is an effect of variable $X$ on variable $Y$.

b. If the value of $\operatorname{sig}>0.05$ or $t$ count $<t$ table, then there is no effect of variable $X$ on variable $\mathrm{Y}$.

The following are the findings of this $t$ test:

\section{Table 3. Test Statistics $t$}

Coefficients $^{\mathrm{a}}$

\begin{tabular}{|c|c|c|c|c|c|}
\hline \multirow[b]{2}{*}{ Model } & \multicolumn{2}{|c|}{$\begin{array}{c}\text { Unstandardized } \\
\text { Coefficients }\end{array}$} & \multirow{2}{*}{$\begin{array}{c}\begin{array}{c}\text { Standardized } \\
\text { Coefficients }\end{array} \\
\text { Beta }\end{array}$} & \multirow[t]{2}{*}{$\mathrm{t}$} & \multirow[b]{2}{*}{ Sig. } \\
\hline & B & Std. Error & & & \\
\hline 1 (Constant) & $-4,133$ & 2,400 & & $-1,722$ & ,089 \\
\hline Tingkat Kepercayaan & ,422 & ,085 & ,372 & 4,969 & , 000 \\
\hline Pengetahuan & 488 & 099 & 394 & 4,917 & 00 \\
\hline Religiusitas & & ,090 & ,261 & 3,423 & ,001 \\
\hline
\end{tabular}

a. Dependent Variable: Minat Muzakki

Based on the aforementioned t-test results for trust, knowledge, and religiosity, it can be inferred that:

a. The confidence level variable has a $t$-count value of 4.969 , which is more than $\mathrm{t}$-table 1.665 (see $\mathrm{t}$-table $\mathrm{df}=\mathrm{n}-\mathrm{k}=80-3=77=1.665$ ) with a significance of 0.000 . The sig value is less than the probability of 0.05 or the value of 
$0.000<0.05$, then $\mathrm{H} 0$ is rejected. The varying level of trust has a favorable and considerable effect on muzakki's interest, it may be determined.

b. The knowledge variable has a t-value of 4.917 which is greater than the $t$ table of 1.665 with a significance of 0.000 . The sig value is less than the probability of 0.05 or the value of $0.000<0.05$, then $\mathrm{H} 0$ is rejected. It can be concluded that the knowledge variable has a positive and significant effect on the interest of muzakki.

c. The religiosity variable has a $\mathrm{t}$-count value of 3.423 which is greater than $\mathrm{t}$ table 1.665 with a significance of 0.001 . The sig value is less than the probability of 0.05 or the value of $0.001<0.05$, then $\mathrm{H} 0$ is rejected. It can be concluded that the religiosity variable has a positive and significant effect on the interest of muzakki.

\section{F Test (Simultaneous Significance Test)}

The Ftest test is used to determine how much the independent variables affect the dependent variable when they are combined. The following is the foundation for making decisions:

a. If the value of sig $<0.05$ or F count $>$ F table, then there is an effect of variable $X$ simultaneously on variable $\mathrm{Y}$.

b. If the value of sig $>0.05$ or F count $<F$ table, then there is no effect of variable $X$ simultaneously on variable $\mathrm{Y}$.

To learn more about the Hasil Uji Simultaneous Penelitian, see the list below.

\section{Table 4. Test Statistics $f$}

ANOVA $^{\mathrm{a}}$

\begin{tabular}{|c|c|c|c|c|c|}
\hline Model & Sum of Squares & $\mathrm{df}$ & Mean Square & $\mathrm{F}$ & Sig. \\
\hline 1 Regression & 355,710 & 3 & 118,570 & 54,556 &, $000^{\mathrm{b}}$ \\
\hline Residual & 165,177 & 76 & 2,173 & & \\
\hline Total & 520,887 & 79 & & & \\
\hline
\end{tabular}

a. Dependent Variable: Minat Muzakki

b. Predictors: (Constant), Religiusitas, Tingkat Kepercayaan, Pengetahuan

Based on table 4. it can be seen that the results of the F-count test in this study amounted to 54.556 with a probability value $(\mathrm{sig})=0.000$. The value of F-count (54.556) > F-table (2.72), and the value of sig is smaller than the probability value of 0.05 or the value of $0.000<0.05$; then Ho is rejected and Ha is accepted, which means that the variables of the level of trust, knowledge, and religiosity together significantly affect the muzakki interest variable.

\section{Discussion}

The following is a breakdown of each hypothesis:

1) The influence of the level of trust (X1) on the interest of muzakki (Y). Based on the first t-test research, the coefficient value of 4.969 is greater than the t-table of 1.665 and the significant value is $0.000<0.05$, then $\mathrm{H} 0$ is rejected. This demonstrates 
that muzakki's interest in issuing zakat at Salatiga City's National Amil Zakat Agency (Baznas) is positively correlated with their degree of trust.

Setiawan (2017) supports this research by stating that muzakki's desire in paying professional zakat through amil zakat institutions is influenced by their level of trust (Setiawan 2018). As a result, it can be inferred that the higher the level of confidence, the greater the interest of muzakki in issuing Zakat Baznas.

2) Effect of Knowledge (X2) on interest in muzakki (Y) . Based on the results of the t-test of 4.917 , which is greater than the t-table of 1.665 with a significance of $0.000<0.05$, then $\mathrm{H} 0$ is rejected. This demonstrates that information has a good and significant impact on muzakki's enthusiasm in issuing zakat at Salatiga City's National Amil Zakat Agency (Baznas).

Isnaini (2018) backs up this claim, claiming that knowing about zakat has a good and significant impact on motivation to pay zakat at zakat homes. This is demonstrated at a far lower level than 0.05, which is 0.000 (Yulinda Isnaini, 2018: 149). Muzakki's motivation in paying zakat is influenced by their knowledge of the zakat. The more muzakki learn about zakat, the more they would want to pay zakat at the management institution.

3) The influence of religiosity (X3) on interest in muzakki (Y). Based on the results of the t-test of 3.423 , it is greater than the t-table of 1.665 with a significance of 0.001 . The sig value is less than the probability of 0.05 or the value of $0.001<0.05$, then $\mathrm{H} 0$ is rejected. It can be concluded that the religiosity variable has a favorable and significant effect on muzakki's enthusiasm in issuing Zakat in Salatiga City's Baznas.

Handrania (2018) backs up this claim, claiming that the religiosity of civil servants (PNS) has a good and significant impact on the desire to pay zakat malls in Bongki village (Handrania, 2018: 111). That is to say, the higher the religiosity, the greater the desire to pay zakat malls in Bongki village. In contrast, if one's religiosity is low, the likelihood of paying zakat mal is likewise low. According to the findings of Arilia and Anwar's (2019) study, the religiosity of Jagad Alimussirry Islamic Boarding School students influences their interest in paying zakat at the amil zakat institution because students have more religious knowledge than people who do not receive education in an Islamic boarding school environment (Linawati Arilia \& Moch. Khoirul Anwar, 2019).

4) The influence between the level of trust (X1), knowledge (X2) and religiosity (X3) on Muzakki's interest (Y). Based on the Fcount test in this study, it was 54.556 with a probability value $(\mathrm{sig})=0.000$. The value of Fcount $(54.556)>$ Ftable (2.72), and the value of sig is smaller than the probability value of 0.05 or the value of $0.000<0.05$; Ho is rejected and Ha is accepted, indicating that the variables of level of trust, knowledge, and religiosity together significantly affect the variable of muzakki's interest in Issuing Zakat at the National Amil Zakat Agency (Baznas) Salatiga City.

Sidiq (2015) supports this research by stating that zakat knowledge has a substantial impact on the desire to pay zakat at amil zakat institutions. The interest 
in paying zakat at amil zakat institutions is also influenced by the amount of confidence. Meanwhile, at a level of 95 percent, the income level variable and the level of religiosity have no meaningful effect (Hanwar Ahmad Sidiq, 2015). This study supports Satrio \& Siswantoro (2016), who claim that income, belief, and religion all have a substantial impact on muzakki's desire to pay zakat through the Amil Zakat Institution (Satrio \& Siswantoro 2016).

\section{E. CONCLUSION}

Based on the previously described research. The following is how it can be concluded: 1) The amount of confidence has a good and significant impact on muzakki's desire in issuing zakat at Salatiga City's National Amil Zakat Agency (Baznas). As a result, the hypothesis has been accepted. The muzakki has a greater incentive to provide zakat if a person has a high level of trust; 2) Knowledge has a favorable and significant impact on muzakki's enthusiasm in issuing zakat at Salatiga City's National Amil Zakat Agency (Baznas). As a result, the hypothesis has been accepted. The amount of knowledge a person has about tithing has a big impact on his or her interest in muzakki since it raises awareness about the responsibility to pay zakat and what it's for; 3) Religion has a favorable and significant impact on muzakki's enthusiasm in issuing zakat at Salatiga City's National Amil Zakat Agency (Baznas). As a result, the hypothesis has been accepted. The higher one's level of religiosity, the greater one's desire to give zakat. This demonstrates that the more the community's religiosity, the more likely people are to pay Zakat through Baznas in Salatiga; 4) The variables of muzakki's interest in granting Zakat at the National Amil Zakat Agency (Baznas) of Salatiga City are highly influenced by their level of trust, knowledge, and religion; 5) The value of the coefficient of determination $\left(\mathrm{R}^{2}\right)$ was 0.683 , according to the results. This suggests that the amount of trust, knowledge, and religion variables may explain 68.3 percent of the muzakki interest variable's contribution.

\section{REFERENCES}

Amir, M. T. (2005). Dinamika Pemasaran. Jakarta: Grafindo Persada.

Ancok, D., \& Fuat, N. S. (2000). Psikologi Islami: Solusi Islam Atas Problem-Problem Psikologi. Yogyakarta: Pustaka Pelajar.

Arilia, L., \& Anwar, M. K. (2019). Pengaruh Religiusitas dan Demografi Santri Pondok Pesantren Jagad, Alimussirry terhadap Minat Membayar Zakat di Lembaga Amil Zakat. Jurnal Ekonomi Islam, 2(2).

Bawono, A. (2006). Multivariate Analysis Dengan SPSS. Salatiga: STAIN Salatiga Press.

Handrania. (2018). Pengaruh Religiusitas Pegawai Negeri Sipil (PNS) Terhadap Minat Membayar Zakat Mal di Kelurahan Bongki Kecamatan Sinjai Utara Kabupaten Sinjai. Makassar: Universitas Islam Negeri Makasar.

Hanwar, A. S. (2015). Pengaruh Pengetahuan Zakat, Tingkat Pendapatan, Religiusitas dan Kepercayaan Organisasi Pengelola Zakat Terhadap Minat Membayar Zakat Pada 
Lembaga Amil Zakat (Studi Kasus Terhadap Muzakki di Fakultas Agama Islam dan Ekonomi Bisnis Universitas Muhammadiyah Surakarta).

Isnaini, Y. (2018). Pengaruh Pengetahuan Zakat, Tingkat Pendapatan, Tingkat Keimanan dan Kepercayaan Terhadap Movitasi Muzakki Profesi (Studi Kasus di Rumah Zakat Cabang Semarang). Universitas Islam Negeri Walisongo, Semarang.

Lusiana, K. (2017). Faktor Determinan Motivasi Membayar Zakat. Sulawesi Selatan: Mediaty.

Nafiah, L. (2015). Pengaruh Pendayagunaan Zakat Produktif Terhadap Kesejahteraan Mustahiq. El-Qist, 5(1).

Nur, M. N., \& Zulfahmi. (2018). Pengaruh Pengetahuan, Pendapatan dan Kepercayaan, Terhadap Minat Muzakki Membayar Zakat di Baitul Mal Kota Lhokseumawe. Ekonomi Regional Unimal, 01(3), 19-29.

BAZNAS Regulation Number 1 of 2016. Guidelines for the Preparation of Annual Work Plans and Budgets for Baznas, Provincial Baznas and Regency and City Baznas.

Laws and Regulations of the Republic of Indonesia Number 38 of 2011. Regarding the management of zakat, the Directorate General of Islamic Community Guidance and Hajj Affairs, Ministry of Religion of the Republic of Indonesia, Jakarta.

Pospos, A. F. (2018). Pengaruh Tingkat Pendapatan, Layanan Dan Kepercayaan Terhadap Minat Pengusaha Warung Kopi Membayar Zakat di Baitul Maal Kota Langsa. At-Tijaroh: Jurnal Ilmu Manajemen dan Bisnis Islam, 4(2), 155.

Salmawati., \& Meutia, F. (2018). Pengaruh Tingkat Pendapatan, Religiusitas, Akuntabilitas dan Kualitas Pelayanan Terhadap Minat Muzakki Membayar Zakat Di Baitul Mal Kota Banda Aceh. Jimeka 3(1), 54-66.

Satrio, E., \& Dodik, S. (2016). Analisis Faktor Pendapatan, Kepercayaan Dan Religiusitas dalam Mempengaruhi Minat Muzakki Untuk Membayar Zakat Penghasilan Melalui Lembaga Amil Zakat. Simposium Nasional Akuntansi XIX, 1(4), 308-15.

Setiawan, E. D. P., \& Fery. (2018). Pengaruh Pendapatan Terhadap Intensi Membayar Zakat Profesi (Studi Kasus Di Kabupaten Ponorogo). Seminar Nasional Dan Call For Paper III.

Setiawan, F. (2017). Pengaruh Religiusitas, Kepercayaan dan Reputasi Terhadap Minat Muzakki dalam Membayar Zakat Profesi (Studi Kasus di Kabupaten Ponorogo). Universitas Muhammadiyah Surakarta.

Sevilla, C. G. (2007). Research Methods. Quezon City: Rex Printing Company.

Siti, K. (2018). Urgensi Peran Amil Zakat di Indonesia Dalam Mewujudkan Kesejahteraan Mustahiq. El-Faqih: Jurnal Pemikiran Dan Hukum Islam, 4(2), 2449.

Sudirman. (2007). Zakat Dalam Arus Modernenitas. Malang: UIN Malang Press.

Yunus, M. (2016). Ekonomi Islam. Program Pascasarjana Universitas Islam Negeri. 